\title{
Market Basket Analysis as a Support Tool for The Management of Public Transport
}

\section{Dorota Sokołowska ${ }^{1}$}

${ }^{1}$ Higher Vocational School in Suwalki, Poland, dorotasokolowska@gazeta.pl

\begin{abstract}
The aim of this paper is to characterize a non-standard use of the method of market basket analysis in one of the areas of economy, i.e. public transport. Generally, one of the aims of the market basket analysis method is associating the consumer's market basket - in the case of public transport this being the choice of bus stops in the city area made by passengers. Owing to a new, practical use of this method, it was possible to build an efficient model characterizing the movement of flows of public transport passengers, and assess the degree of transferring (changing lines), thus making it possible to adapt the routes of buses to the needs of people using this particular means of transport, as well as to plot new communication lines.

The data analysis was performed using the Statistica statistical package and its SAL application, i.e. the algorithms used in Data Mining.

Keywords: market basket analysis, data mining, SAL, associations and sequences, flows of passengers, decision
\end{abstract}

\section{Introduction}

Public transport - its organization and effective management - is a challenge for both transporters and municipal authorities, the trust and satisfaction of the client - a potential citizen - being the primary concern. In times of rapid economic changes, when shifts in population density due to, for example, the construction of new housing estates or "disappearance" of large enterprises replaced by smaller ones, there is a tendency for population centers to concentrate or deconcentrate. A public transport system in use must, on the one hand, ensure citizen safety and be stable, and respond to changes and be adapted to emerging needs, on the other. From the economic point of view, the difficulties that need to be considered in the area of transport have multiple facets, such as the financial aspects (including the distribution of costs, donations, used and refinanced allowances), the aspects of organization arising from demand, or service quality control. 


\section{Dorota Sokołowska}

A basis for solving problems in this field is the broadly understood knowledge in the area of employing means essential for transporting passengers in the area of the city and the adjacent communities. The matter of projecting the flow of passengers has already been studied with the use of various methods: the nested logit model (Gangrade, Pendyala, McCullough, 2002, p. 17-26), Markov's chains (Lerman, 1979, p. 273-291), through estimating the value of the expected number of passengers transported yearly by a single communication line (Dytkowski, Gamrot, Tomanek, 2009, p. 7598), or by studying patterns of passengers' behavior and, perhaps the most importantly, the distribution of travel routes with the use of data collected by electronic ticket vending devices (Navick, Furth, 2002, p. 107-113).

The subject of the discussion presented in this article is the issue of the estimation of flows of passengers using the public transport buses in Białystok. The population of the urban agglomeration is approx. 370,000 persons, of which 295,000 live in the city proper. The city of Białystok ranks fourth in Poland (among cities with district rights) in terms of population density, amounting to 2888 persons $/ \mathrm{km}^{2}$ (Area and Population in the Territorial Profile in 2013, Central Statistical Office). The Białystok Public Transport Company (Białostocka Komunikacja Miejska - BKM) has a fleet of 268 buses, transporting 100,000,000 passengers a year. (Information obtained from the Białystok Public Transport Company). The modern passenger counting systems mounted in the buses, make it possible to generate large databases and allow to perform multi-criteria analyses, which are an essential support tool for decisions connected with the organization of transport in general.

\section{Market basket analysis}

In order to perform an effective data analysis, one of the most popular association rules, i.e. the market basket analysis, was used. Its underlying idea is to determine the market basket that the customer collects in a single place (e.g. a shop, a company, the exchange) or within a specified time period (e.g. a day, a month, a year). Among the aims of the market basket analysis, the most important ones are (Łapczyński, 2009):

- to offer optimization in order to increase the sale of a product (determination of the market basket purchased by customers);

- to find all the rules containing characteristics of association between products (detecting characteristic traits of behavior of consumers purchasing goods);

- to determine the sequence of purchase of goods. 
The market basket analysis belongs to the group of models based on association. Association models take the form of the "if $A$ then $B$ " conditional sentences, which means that there is a co-existence of two sentence elements in a specific order. This sequence is a simple implication, which when used for the market basket analysis, describes the purchase of a specific Commodity $A$, which implies the purchase of Commodity $B$ with a certain probability.

The basic qualitative measures describing the association rules are the support ratio and the confidence ratio. These measures can be expressed as:

$$
\text { support }=P(A \cap A)=\frac{\text { number of transactions containing } A \text { and } B}{\text { the total number of transactions }}
$$

which is the probability of a customer purchasing Products $A$ and $B$ at the same time, and

$$
\text { confidence }=P(A / B)=\frac{P(A \cap B)}{P(A)}
$$

where $P(A)$ is the number of transactions including $A$ which is the probability of purchase of Product $B$ among those customers that have already purchased Product $A$.

An innovative use of the market basket analysis is the analysis of passenger traffic in public transport, where passengers are customers by analogy, while the commodities they choose are the bus stops they use when they start and finish their journeys. Positive results of the use of the market basket analysis are only possible for large data sets. (Harańczyk, 2010). Creating such sets in the era of digitization is not a difficult undertaking. Examples of such sets are product barcodes, addresses, bank card numbers, or bus ticket numbers collected in databases or data banks. The enormity of data may give the impression of chaos at first glance, but for a researcher, this constitutes an endless possibility for gaining knowledge. Data browsing and exploration, called Data Mining, is a relatively new branch of science, rapidly developing together with the development of digitization. (Migut, 2009). Data exploration techniques make it possible to find, or discover, previously unknown correlations and patterns, which may be used to facilitate the decision-making process or to describe a database. By means of the right algorithm, rules, decision trees, or neural nets may be generated.

In the undertaken research, due to the volume of the database and the specific character of the data, association rules available in the SAL module (Sequence, Association and Link Analysis) included in the Statistica v.10 


\section{Dorota Sokołowska}

package were used. This application provides the user with a set of computational and graphic tools for mining association rules and visualizing them in the form of graphs.

\section{Preliminary data analysis}

In order to effectively manage the public transport system and for its effective optimization, readers, whose tasks include counting passengers in an automated manner, were mounted in public transport buses in Białystok. Data is collected continually in the form of user-friendly tables and graphs, and then sent to the person managing the vehicle fleet. Owing to its automated character, the system makes it possible to obtain exact data, characterized by repeatability. The data pertains to, for instance, the structure and number of passengers, duration of a journey, or its starting place, and thus to the flow on individual routes, the bus number, and the driver number.

When applying the market data analysis to investigating flows of passenger movement, two crucial problems appeared. The first one was of technical nature, the other was content-related. Firstly, using the market basket analysis, one has to create a matrix, whose rows correspond to successive passengers, while the columns describe bus stops. Due to the multimillionrecord database, such analysis would be extremely difficult. The other problem was the database itself, which was created as the result of recording impulses generated from electronic cards used on entering the bus at the moment the journey started. There is, however, no data that would unambiguously indicate where the passenger finished their journey.

Due to the lack of information concerning the place the journey finishes and considering the size of the database, advanced statistical methods with the use of the latest version of the Statistica (v10) package were employed. Methods of association and sequence analysis (SAL) were especially important in the calculations. This is a type of statistical analysis whose aim is to identify the combination of values of variables occurring with a certain frequency and regularity in a data set. In other words, the SAL application "counts" passengers with the same characteristic features, e.g. those using the same bus stops. In the case of an analysis of urban connections, this means projecting with a certain probability the places where a passenger will appear, knowing where they entered the bus.

Sequence analysis, used to study transferring, also played an important role in the description of flows of public transport passengers. It was also 
used to describe directions of movement of passengers riding on public transport buses starting their journey in a specific place by taking into account the chronological order of e-card log-ins in successive locations. Additionally, data at the level of individual bus stops was analyzed, indicating those that were the most popular, and pairs of bus stops at which the same cards were logged-in were pointed out.

For the purpose of the research, information from the counting system of the passengers using the Białystok Public Transport and registering their journeys by means of the e-card was selected. The range of data covered two one-month periods: October 2012 and March 2013. The choice of months for the analysis was not accidental. Its aim was to single out the most representative months that would reflect typical behavior of passengers using the public transport in Białystok - this is why holiday and school break months were excluded. The database contained 3,943,664 records, describing the journeys of 68,097 passengers in October 2012 and 3,418,235 records, describing the journeys of 69,060 passengers in March 2013. For the purpose of the calculations, information such as e-card ID, date and time, and the place (line umber and bus stop name) of registration of each of the journeys was used. An assumption was made that each ecard corresponds to a single passenger using the public transport. The analysis does not contain information concerning the passengers riding on the public transport in Białystok who use allowances or privileges (e.g. pensioners or annuitants), nor persons using traditional (paper) tickets. It is assumed that the proportion of persons not registered by means of the card readers is approx. 50\% of all the passengers. (Information obtained from BKM Management). In addition, the city was divided into 36 parts, consistent geographically, administratively, communication-wise. Together with the 6 communes serviced by BKM, the total number of areas, called Regions, was 41 . Then, the bus stops located in individual regions were grouped.

Preliminary data investigation made it possible to:

- analyze the number of electronic cards (equivalent to passengers) logged-in in the area of the individual regions serviced by BKM;

- determine the number of passengers moving between pairs of regions;

- identify the most popular connections;

- perform an analysis of the movement of passengers from individual residential areas.

The total numbers of recorded journeys, as well as all e-cards used, in the analyzed months on all lines and all bus stops serviced by BKM are presented in the table below and on the graphs. 
Dorota Sokolowska

Table 1

Number of recorded e-cards and journeys in the analyzed months

\begin{tabular}{|l|r|r|}
\hline \multicolumn{1}{|c|}{ Information } & Oct 2012 & Mar 2013 \\
\hline number of journeys (log-ins) & $3,943,664$ & $3,418,235$ \\
number of passengers (cards used) & 68,097 & 69,060 \\
number of bus stops (according to recorded log-ins) & 836 & 817 \\
Number of lines (according to recorded log-ins) & 39 & 43 \\
\hline
\end{tabular}

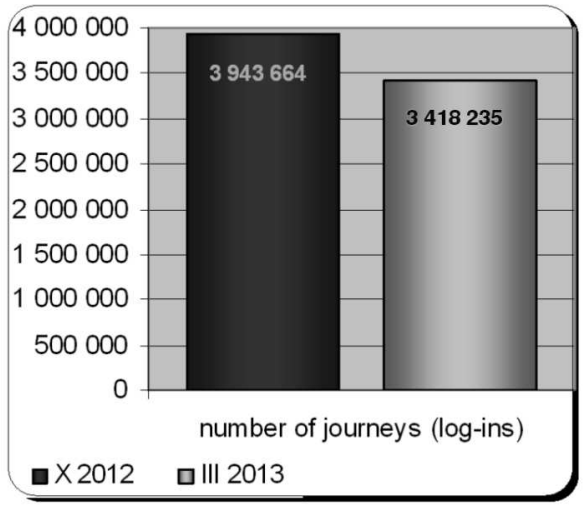

Figure 1. Recorded journeys

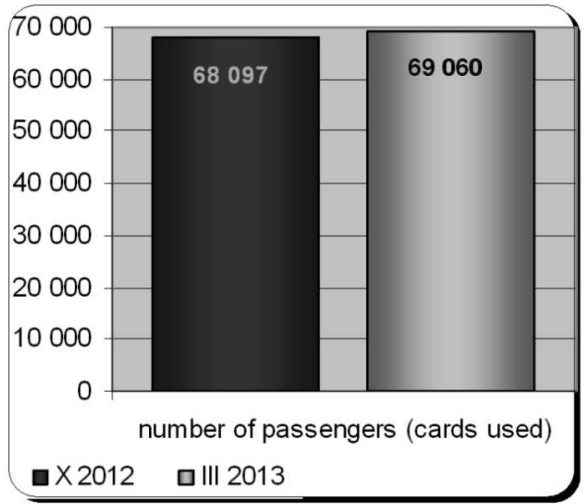

Figure 2. Recorded e-cards

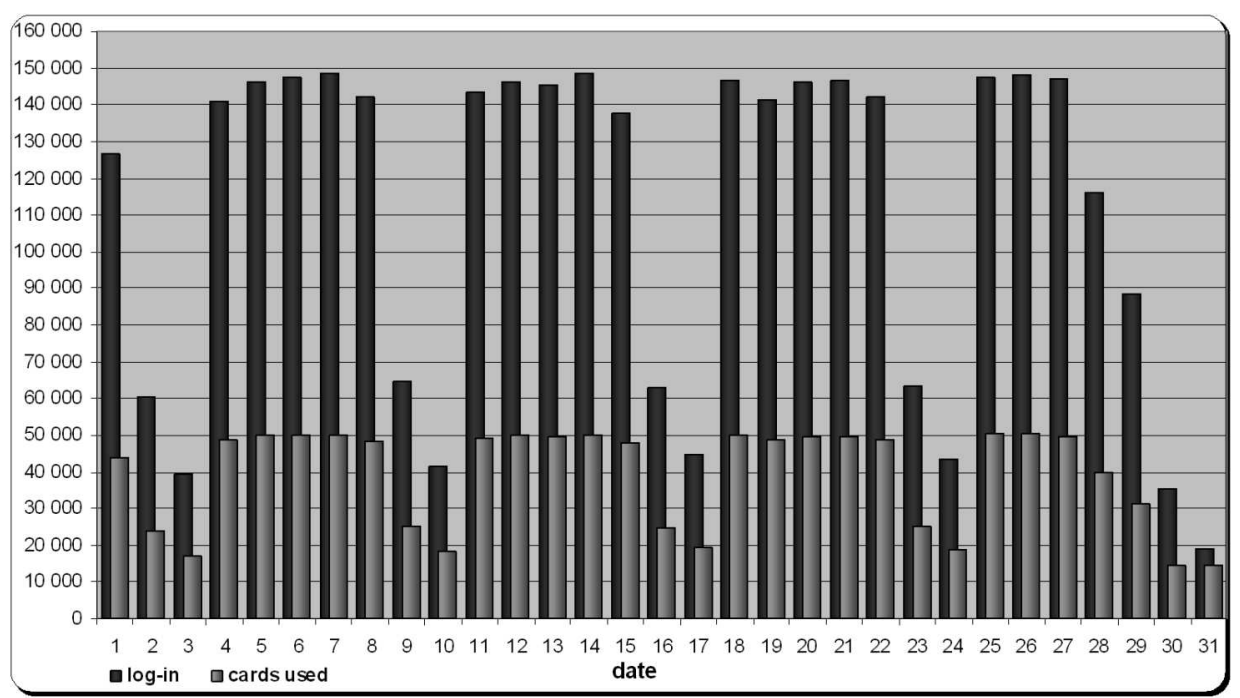

Figure 3. Distribution of recorded e-cards and journeys on individual days of March 2013 
When analyzing the data from October 2012 and March 2013, a greater number of e-cards in March 2013, by almost 1000 units (+1.4\%), can be observed. Despite the greater number of passengers using the e-card, a smaller number of journeys of these passengers, by over 500,000 (-13.3\%), was recorded. However, on the basis of the data from other months, it can be stated that the numbers of journeys of passengers differ only slightly in fact, therefore, all further analysis was based on the data from March 2013, as it is the month with the highest number of persons traveling, but also because it was more recent in comparison with the October of the previous year.

On the basis of the analysis of the public transport bus journeys recorded by means of the e-cards on individual days of March 2013, it can be stated that the numbers of journeys on individual workdays (from Monday to Friday) are similar; as are the numbers of journeys on individual Saturdays and Sundays. A significant difference in the number of recorded e-cards and journeys (log-ins) can be noticed, on the other hand, between workdays and Saturdays and Sundays.

\section{Analysis of passenger traffic between Regions}

Due to the small difference between the number of journeys in successive workdays in March, shown above, a detailed analysis of passenger movement on a single workday allows to estimate the whole structure of traffic from Monday do Friday. An assumption was made that the analyzed day will be March 7, 2013, owing to the highest number of journeys out of all the days of this month. All the data below pertains to this chosen day.

The system of data concerning BKM passengers using e-cards allows to accurately ascribe each log-in (on entering the bus) in the system to individual bus stops, whereas ascribing bus stops to the appointed Regions (parts of the city and the surrounding communes) makes it possible, in turn, to ascribe all e-card log-ins to them.

\section{Daily data from individual Regions}

Using the Statistica package and by ascribing bus stops to individual Regions, daily numbers of passengers using e-cards recording their journeys in the area of each of the Regions were determined.

a 
Table 2

Daily number of log-ins (passengers) in the area of individual Regions. (The names of Regions are left in their original form)

\begin{tabular}{|c|c|}
\hline Region & $\begin{array}{l}\text { Number of } \\
\text { passengers }\end{array}$ \\
\hline Centrum Wschód & 17500 \\
\hline Wiejska_Kawaleryjska & 8029 \\
\hline Centrum Zachód & 7430 \\
\hline Piaski & 6430 \\
\hline Wysoki Stoczek & 6293 \\
\hline Osiedle Młodych & 6014 \\
\hline Sienkiewicza_Wasilkowska & 5990 \\
\hline Sady Antoniukowskie & 5571 \\
\hline PKP_PKS & 4944 \\
\hline Branickiego_Warszawska & 4496 \\
\hline Dziesięciny & 4367 \\
\hline Piasta & 4056 \\
\hline Zielone Wzgórza & 3895 \\
\hline Mickiewicza_urzędy & 3787 \\
\hline Nowe Miasto & 3513 \\
\hline Słoneczny Stok & 3281 \\
\hline Bażantarnia & 3164 \\
\hline TBS & 2933 \\
\hline Kawaleryjska_Kleosin & 2690 \\
\hline Białostoczek & 2489 \\
\hline Skorupy_Przemysłowe & 2420 \\
\hline Leśna Dolina & 2073 \\
\hline Dojlidy & 2027 \\
\hline Starosielce & 1802 \\
\hline Wygoda_Chełmońskiego & 1684 \\
\hline Pietrasze & 1407 \\
\hline Jaroszówka_Wyżyny & 1198 \\
\hline Białostoczek przemysłowy & 1113 \\
\hline DOBRZYNIEWO & 821 \\
\hline Bacieczki & 788 \\
\hline Dojlidy Górne & 612 \\
\hline WÁSILKÓW & 587 \\
\hline SUPRAŚL & 585 \\
\hline Starosielce przemysłowe & 579 \\
\hline Jurowiecka_Poleska_BohGetta & 493 \\
\hline CHOROSZCZ & 410 \\
\hline Pieczurki & 404 \\
\hline JUCHNOWIEC & 391 \\
\hline Mickiewicza_osiedle & 369 \\
\hline Zawady & 335 \\
\hline ZABEUDÓW & 29 \\
\hline
\end{tabular}




\section{Flows of passengers and determining the most popular pairs of Regions}

When entering the bus, each of the passengers must register their ride; when they leave the bus, they are not obliged to do the same. In this study, an assumption was formulated whereby the finishing point of a journey was the same place where the return journey of a specific passenger started (recorded by means of the same e-card). Based on the association of a specific e-card number, the numbers of passengers traveling between two points can be counted. It must be noticed, however, that the analysis pertains to a single day only, thus the passengers who started their journey on the $7^{\text {th }}$ of March and returned on the following day (or the other way around - finished their journey in the analyzed day) are excluded from the study for technical reasons, i.e. the lack of a "pair" for the e-card number that could be associated with it. The number of such passengers is about 7,000 , which amounts to approximately $10 \%$ of those traveling on the studied day.

Hence, with the use of the association analysis (in the investigated set of passenger log-ins in individual Regions of the city), the probability of where a passenger will appear, knowing where they entered the bus could be determined. Converting the probability of a passenger traveling in a certain direction into the number of passengers, an estimated number of these passengers traveling between two specific locations in the course of a day can be determined.

Using the aforementioned method, the numbers of passengers traveling between the assigned regions were determined, without taking into account their order.

Table 3

The most popular pairs of Regions

\begin{tabular}{|c|c|c|}
\hline Region & Region & $\begin{array}{c}\text { Number of } \\
\text { passengers }\end{array}$ \\
\hline Centrum Wschód & Centrum Zachód & 2831 \\
Centrum Wschód & Sienkiewicza_Wasilkowska & 2245 \\
Centrum Wschód & Wiejska_Kawaleryjska & 2162 \\
Branickiego_Warszawska & Centrum Wschód & 2033 \\
Centrum Wschód & Osiedle Młodych & 1935 \\
Centrum Wschód & Piaski & 1907 \\
Centrum Wschód & Piasta & 1839 \\
Centrum Wschód & Mickiewicza_urzędy & 1754 \\
Centrum Wschód & Wysoki Stoczek & 1721 \\
\hline
\end{tabular}




\begin{tabular}{|c|c|c|}
\hline Region & Region & $\begin{array}{l}\text { Number of } \\
\text { passengers }\end{array}$ \\
\hline Centrum Wschód & Sady Antoniukowskie & 1693 \\
\hline Wiejska_Kawaleryjska & Piaski & 1616 \\
\hline Centrum Wschód & PKP_PKS & 1460 \\
\hline Białostoczek & Centrum Wschód & 1363 \\
\hline Centrum Wschód & Skorupy_Przemysłowe & 1351 \\
\hline Kawaleryjska_Kleosin & Wiejska_Kawaleryjska & 1330 \\
\hline Centrum Wschód & Dziesięciny & 1230 \\
\hline Centrum Zachód & Sienkiewicza_Wasilkowska & 1202 \\
\hline Centrum Wschód & Dojlidy & 1157 \\
\hline Sady Antoniukowskie & Wysoki Stoczek & 1145 \\
\hline Centrum Zachód & Osiedle Młodych & 1117 \\
\hline Nowe Miasto & Wiejska_Kawaleryjska & 1085 \\
\hline Centrum Zachód & Sady Antoniukowskie & 1059 \\
\hline Centrum Zachód & Wysoki Stoczek & 1028 \\
\hline Sienkiewicza_Wasilkowska & Wiejska_Kawaleryjska & 1004 \\
\hline Centrum Wschód & Słoneczny Stok & 977 \\
\hline Centrum Wschód & Zielone Wzgórza & 928 \\
\hline Dziesięciny & Sady Antoniukowskie & 912 \\
\hline Wysoki Stoczek & TBS & 911 \\
\hline Centrum Wschód & TBS & 906 \\
\hline Centrum Wschód & Nowe Miasto & 868 \\
\hline Bażantarnia & Wiejska_Kawaleryjska & 849 \\
\hline Osiedle Młodych & Wysoki Stoczek & 830 \\
\hline Dziesięciny & Wysoki Stoczek & 822 \\
\hline Branickiego_Warszawska & Centrum Zachód & 792 \\
\hline Osiedle Młodych & Słoneczny Stok & 781 \\
\hline Osiedle Młodych & PKP_PKS & 751 \\
\hline Centrum Zachód & Piaski & 743 \\
\hline Sienkiewicza_Wasilkowska & Piaski & 732 \\
\hline Centrum Wschód & Wygoda_Chełmońskiego & 729 \\
\hline Centrum Wschód & Leśna Dolina & 719 \\
\hline Centrum Zachód & PKP_PKS & 688 \\
\hline Osiedle Młodych & Sady Antoniukowskie & 687 \\
\hline Branickiego_Warszawska & Skorupy_Przemysłowe & 685 \\
\hline Centrum Wschód & Jaroszówka_Wyżyny & 668 \\
\hline Bażantarnia & Centrum Wschód & 666 \\
\hline Osiedle Młodych & Zielone Wzgórza & 663 \\
\hline PKP_PKS & Wiejska_Kawaleryjska & 645 \\
\hline Dziesięciny & Sienkiewicza_Wasilkowska & 630 \\
\hline Centrum Zachód & Mickiewicza_urzędy & 628 \\
\hline
\end{tabular}

Using the package, the data from Table 3 was visualized on a net graph. 
Market Basket Analysis as a Support Tool for The Management...

Wykres sieciowy

Wielkość węzła: względne wsparcie każdego elementu

Gubość linii: względne wsparcie dla dwóch elementów

Jasność koloru linii: względny przyrost elementów

Warunek uwzgl ędniania: Dzien=7

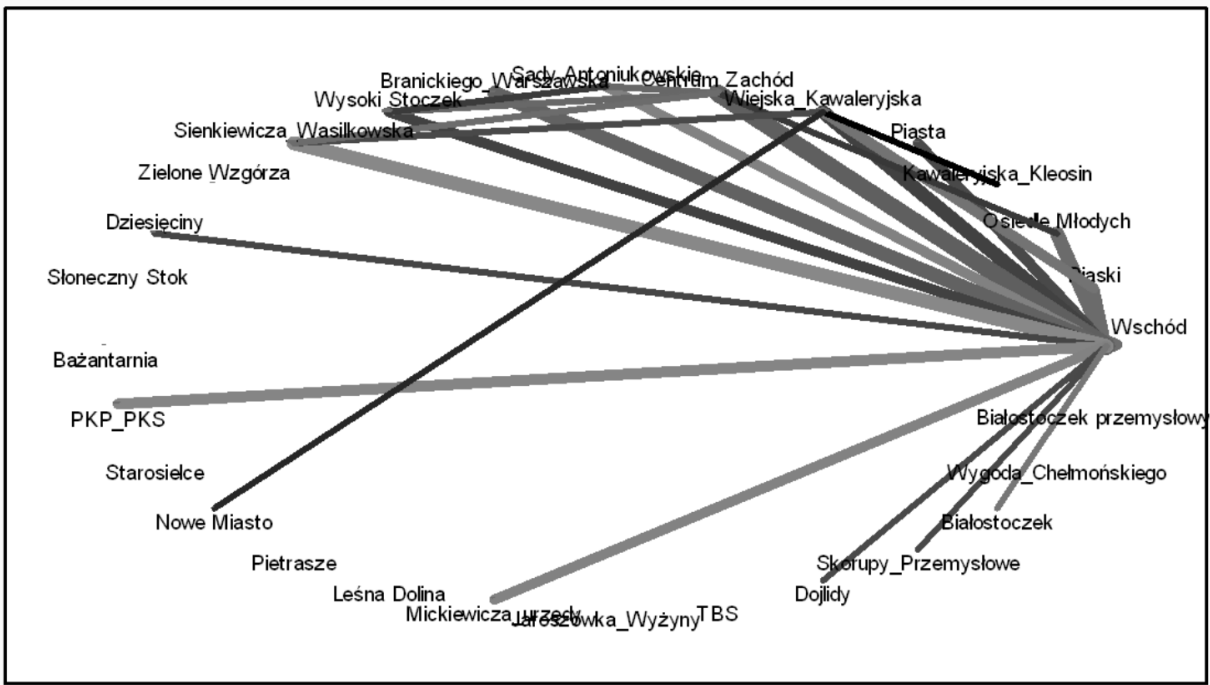

[Net graph]

[Node size: relative support for each element]

[Line thickness: relative support for two elements]

[Brightness of line color: relative increment of elements]

[Condition for inclusion: Day $=7$ th]

Figure 4. The largest flows of passengers between Regions

Lack of connection between Regions indicates the number of passengers below the assumed support level.

As shown by the tables and the graph above, among the most popular directions of movement of passengers, the Region specified as Centrum Wschód is the dominant one. It is safe to assume that this place plays the role of the city's "transfer centre". Paths of most of the passengers using BKM services cross at this location. This is even more visible when the main flows of passengers are plotted on the map of Białystok. (The map was used with permission of the Białystok Municipal Office).

In order to better assess traffic distribution outside the dominant place, an analysis identical to the earlier one was performed, this time with the dominant point excluded. Using the Statistica package, the numbers of passengers traveling between the appointed regions (with the exclusion of the Centrum Wschód Region) were determined. 


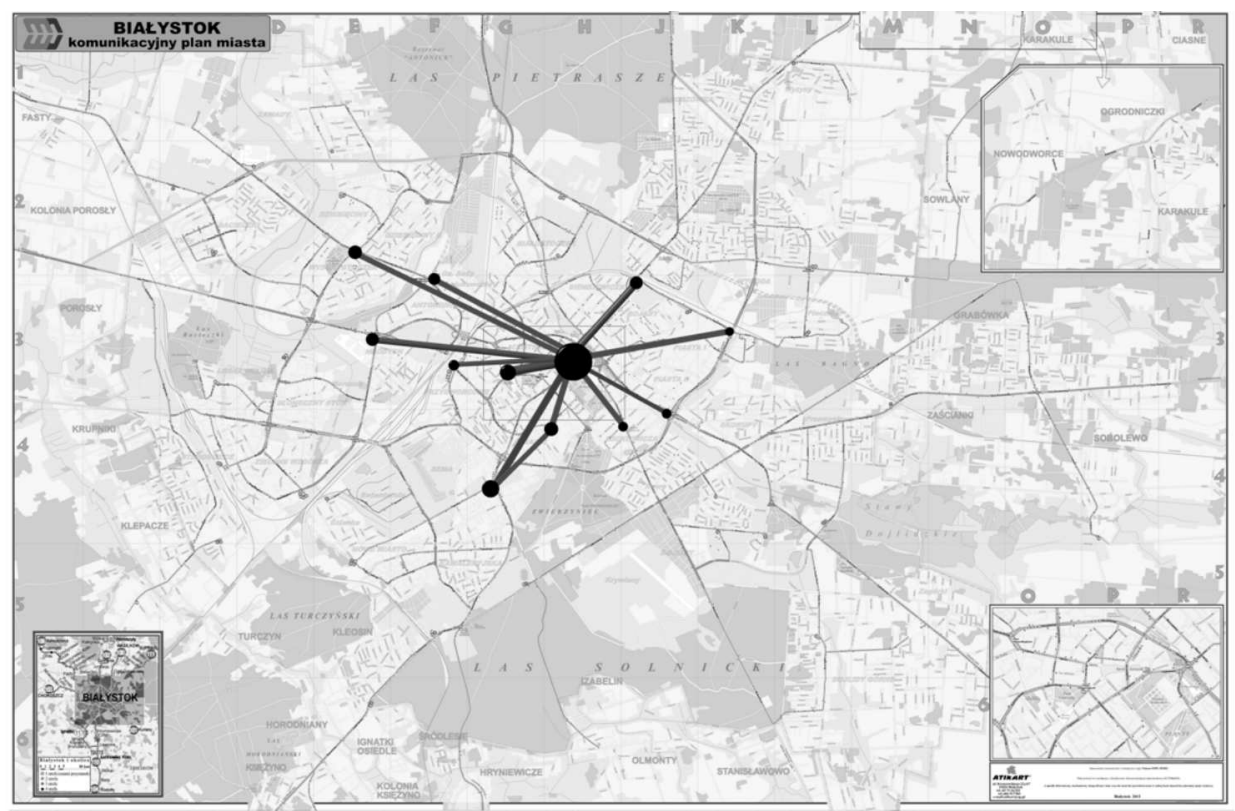

Figure 05. Main flows of passengers in Białystok

Table 4

The most popular pairs of Regions (without the Centrum Wschód Region)

\begin{tabular}{|c|c|c|}
\hline Region & Region & $\begin{array}{c}\text { Number of } \\
\text { passengers }\end{array}$ \\
\hline Wiejska_Kawaleryjska & Piaski & 1616 \\
Kawaleryjska_Kleosin & Wiejska_Kawaleryjska & 1330 \\
Centrum Zachód & Sienkiewicza_Wasilkowska & 1202 \\
Sady Antoniukowskie & Wysoki Stoczek & 1145 \\
Centrum Zachód & Osiedle Młodych & 1117 \\
Nowe Miasto & Wiejska_Kawaleryjska & 1085 \\
Centrum Zachód & Sady Antoniukowskie & 1059 \\
Centrum Zachód & Wysoki Stoczek & 1028 \\
Sienkiewicza_Wasilkowska & Wiejska_Kawaleryjska & 1004 \\
Dziesięciny & Sady Antoniukowskie & 912 \\
Wysoki Stoczek & TBS & 911 \\
Bażantarnia & Wiejska_Kawaleryjska & 849 \\
Osiedle Młodych & Wysoki Stoczek & 830 \\
Dziesięciny & Wysoki Stoczek & 822 \\
Branickiego_Warszawska & Centrum Zachód & 792 \\
Osiedle Młodych & Słoneczny Stok & 781 \\
\hline
\end{tabular}


Market Basket Analysis as a Support Tool for The Management...

\begin{tabular}{|c|c|c|}
\hline Region & Region & $\begin{array}{l}\text { Number of } \\
\text { passengers }\end{array}$ \\
\hline Osiedle Młodych & PKP_PKS & 751 \\
\hline Centrum Zachód & Piaski & 743 \\
\hline Sienkiewicza_Wasilkowska & Piaski & 732 \\
\hline Centrum Zachód & PKP_PKS & 688 \\
\hline Osiedle Młodych & Sady Antoniukowskie & 687 \\
\hline Branickiego_Warszawska & Skorupy_Przemysłowe & 685 \\
\hline Osiedle Młodych & Zielone Wzgórza & 663 \\
\hline PKP_PKS & Wiejska_Kawaleryjska & 645 \\
\hline Dziesięciny & Sienkiewicza_Wasilkowska & 630 \\
\hline Centrum Zachód & Mickiewicza_urzędy & 628 \\
\hline Kawaleryjska_Kleosin & Piaski & 616 \\
\hline Sady Antoniukowskie & Wiejska_Kawaleryjska & 600 \\
\hline Centrum Zachód & Wiejska_Kawaleryjska & 594 \\
\hline Nowe Miasto & Piaski & 593 \\
\hline Branickiego_Warszawska & Osiedle Młodych & 592 \\
\hline Sienkiewicza_Wasilkowska & Wygoda_Chełmońskiego & 582 \\
\hline Osiedle Młodych & Piaski & 580 \\
\hline Bażantarnia & Osiedle Młodych & 559 \\
\hline Osiedle Młodych & Bażantarnia & 559 \\
\hline PKP_PKS & Wysoki Stoczek & 548 \\
\hline Centrum Zachód & Piasta & 547 \\
\hline Pietrasze & Sienkiewicza_Wasilkowska & 542 \\
\hline PKP_PKS & Sady Antoniukowskie & 541 \\
\hline Centrum Zachód & Pietrasze & 537 \\
\hline Sienkiewicza_Wasilkowska & Wysoki Stoczek & 535 \\
\hline Sady Antoniukowskie & Piaski & 527 \\
\hline PKP_PKS & Sienkiewicza_Wasilkowska & 509 \\
\hline Centrum Zachód & Zielone Wzgórza & 496 \\
\hline Mickiewicza_urzędy & Piaski & 488 \\
\hline PKP_PKS & Piaski & 485 \\
\hline Centrum Zachód & Dziesięciny & 482 \\
\hline Osiedle Młodych & TBS & 482 \\
\hline Wiejska_Kawaleryjska & Wysoki Stoczek & 480 \\
\hline Sady Antoniukowskie & Sienkiewicza_Wasilkowska & 474 \\
\hline
\end{tabular}

In order to visualize the main flows of passengers on net graphs in a legible manner, support estimate values of $2 \%$ and $1.5 \%$ were used.

An analysis of data with the exclusion of the "transfer" Region of Centrum Wschód showed that the greatest number of passenger journeys to other Regions are started from: Wiejska_Kawaleryjska, Centrum_Zachód, Sienkiewicza_Wasilkowska, and Sady Antoniukowskie. 
a) a journey of at least $2 \%$ of the total number of passengers (approx. 1000 passengers)

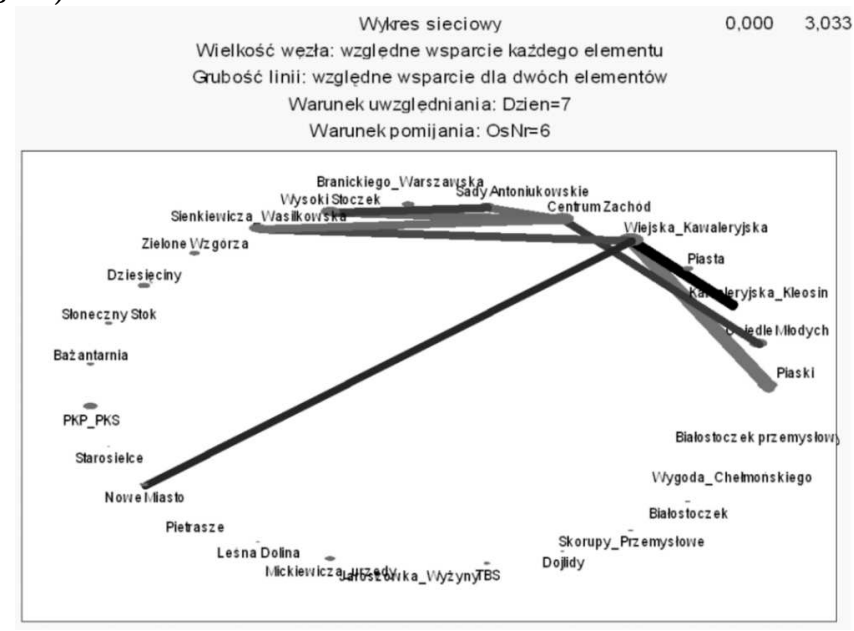

[Net graph]

[Node size: relative support for each element]

[Line thickness: relative support for two elements]

[Condition for inclusion: Day $=7 \mathrm{th}$ ]

b) a journey of at least $1,5 \%$ of the total number of passengers (approx. 780 passengers)

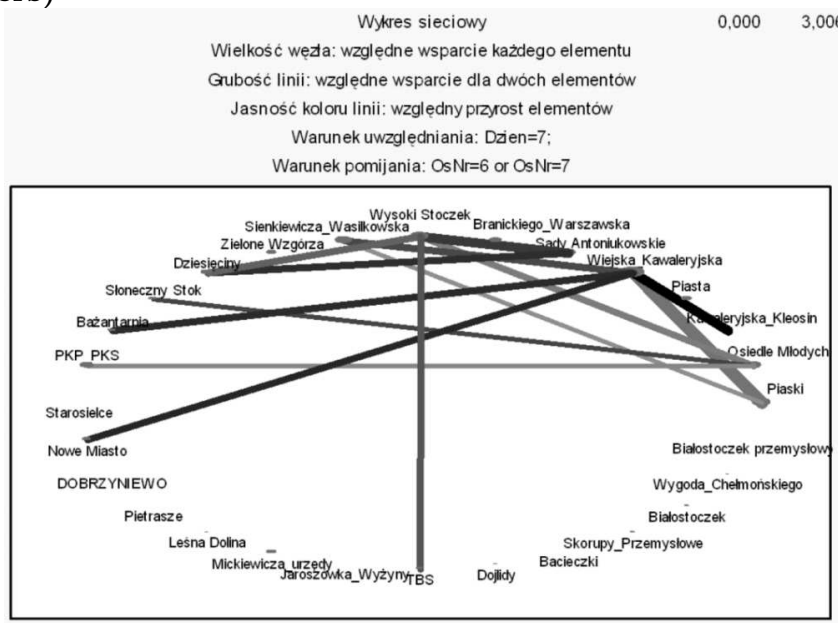

[Net graph]

[Node size: relative support for each element]

[Line thickness: relative support for two elements]

[Brightness of line color: relative increment of elements]

[Condition for inclusion: Day $=7$ th]

Figure 6. The largest flows of passengers between Regions (without Centrum Wschód) 
Market Basket Analysis as a Support Tool for The Management...

\section{Passenger traffic sequence analysis - a study of transferring}

Sequence analysis, unlike association analysis, allows to analyze, in addition to their number, the directions of movement of passengers, by taking into account the chronological order of e-card log-ins in successive locations on the investigated day.

An example visualization of the direction of the flow of passengers from the Centrum Wschód Region (the middle part of the graph) is presented in the radar graph below.

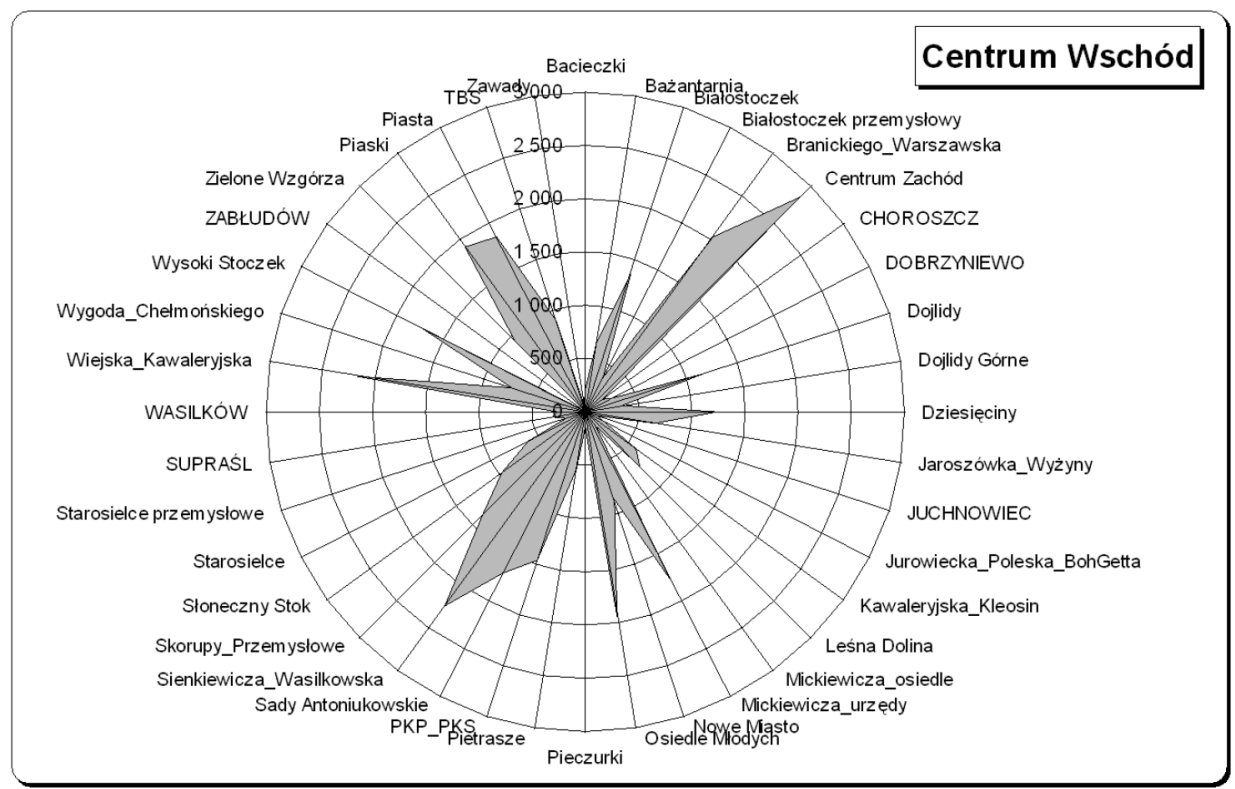

Figure 7. Numbers of passengers traveling from the Centrum Wschód Region

As can be noticed, Centrum Wschód is an important point on the public transport map. This is the result of the radial arrangement of the city on the one hand, and of thus organized network of connections of bus communication on the other.

Using sequence analysis in the Statistica package, an investigation of the movement of passengers between two, three and four successive locations respectively was performed, compiled on the example spreadsheet. 
Table 5

E-card log-ins in two successive Regions (example numbers from an Excel spreadsheet, sorted in descending order)

\begin{tabular}{|c|c|c|}
\hline Region 1 & Region 2 & $\begin{array}{c}\text { Number of } \\
\text { passengers }\end{array}$ \\
\hline Sienkiewicza_Wasilkowska & Centrum Wschód & 1671 \\
Centrum Wschód & Centrum Zachód & 1652 \\
Wiejska_Kawaleryjska & Centrum Wschód & 1609 \\
Centrum Zachód & Centrum Wschód & 1556 \\
Piasta & Centrum Wschód & 1481 \\
Branickiego_Warszawska & Centrum Wschód & 1415 \\
Wysoki Stoczek & Centrum Wschód & 1318 \\
Piaski & Centrum Wschód & 1291 \\
Mickiewicza_urzędy & Centrum Wschód & 172 \\
Osiedle Młodych & Centrum Wschód & 1144 \\
Białostoczek & Centrum Wschód & 1123 \\
Centrum Wschód & Osiedle Młodych & 1094 \\
Sady Antoniukowskie & Centrum Wschód & 1090 \\
Skorupy_Przemysłowe & Centrum Wschód & 1084 \\
Dziesięciny & Centrum Wschód & 1050 \\
Kawaleryjska_Kleosin & Wiejska_Kawaleryjska & 1029 \\
Centrum Wschód & Branickiego_Warszawska & 1025 \\
Wiejska_Kawaleryjska & Piaski & 1021 \\
Centrum Wschód & Sienkiewicza_Wasilkowska & 979 \\
Centrum Wschód & Wiejska_Kawaleryjska & 974 \\
\hline
\end{tabular}

\section{Table 6}

E-card log-ins in three successive Regions (example numbers from an Excel spreadsheet, sorted in descending order)

\begin{tabular}{|c|c|c|c|}
\hline Region 1 & Region 2 & Region 3 & $\begin{array}{c}\text { Number of } \\
\text { passengers }\end{array}$ \\
\hline Centrum Wschód & Centrum Wschód & Centrum Zachód & 269 \\
Wiejska_Kawaleryjska & Wiejska_Kawaleryjska & Wiejska_Kawaleryjska & 268 \\
Kawaleryjska_Kleosin & Wiejska_Kawaleryjska & Wiejska_Kawaleryjska & 265 \\
Wysoki Stoczek & Wysoki Stoczek & Wysoki Stoczek & 262 \\
Wiejska_Kawaleryjska & Centrum Wschód & Wiejska_Kawaleryjska & 259 \\
Wiejska_Kawaleryjska & Kawaleryjska_Kleosin & Wiejska_Kawaleryjska & 253 \\
Wiejska_Kawaleryjska & Piaski & Wiejska_Kawaleryjska & 247 \\
Sienkiewicza_Wasilkowska & Centrum Wschód & Centrum Zachód & 235 \\
Piasta & Centrum Wschód & Piasta & 226 \\
Sienkiewicza_Wasilkowska & Centrum Wschód & Sienkiewicza_Wasilkowska & 219 \\
Centrum Wschód & Centrum Wschód & Sienkiewicza_Wasilkowska & 204 \\
Wiejska_Kawaleryjska & Wiejska_Kawaleryjska & Piaski & 189 \\
Centrum Wschód & Centrum Wschód & Branickiego_Warszawska & 179 \\
Nowe Miasto & Wiejska_Kawaleryjska & Nowe Miasto & 172 \\
Centrum Wschód & Centrum Wschód & Mickiewicza_urzędy & 171 \\
Centrum Wschód & Centrum Wschód & Osiedle Młodych & 169 \\
Wysoki Stoczek & Centrum Wschód & Wysoki Stoczek & 168 \\
Centrum Wschód & Centrum Wschód & Wiejska_Kawaleryjska & 162 \\
Centrum Wschód & Centrum Wschód & Sady Antoniukowskie & 157 \\
\hline
\end{tabular}


Table 7

E-card log-ins in four successive Regions

(example numbers from an Excel spreadsheet, sorted in descending order)

\begin{tabular}{|c|c|c|c|c|}
\hline Region 1 & Region 2 & Region 3 & Region 4 & $\begin{array}{c}\text { Number of } \\
\text { passengers }\end{array}$ \\
\hline Wysoki Stoczek & Wysoki Stoczek & Wysoki Stoczek & Wysoki Stoczek & 53 \\
Kawaleryjska_Kleosin & Wiejska_Kawaleryjska & Wiejska_Kawaleryjska & Kawaleryjska_Kleosin & 49 \\
Wiejska_Kawaleryjska & Wiejska_Kawaleryjska & Wiejska_Kawaleryjska & Piaski & 40 \\
Sienkiewicza_Wasilkowska & Centrum Wschód & Centrum Zachód & Sienkiewicza_Wasilkowska & 37 \\
Sienkiewicza_Wasilkowska & Centrum Wschód & Sienkiewicza_Wasilkowska & Centrum Zachód & 36 \\
Piasta & Centrum Wschód & Piasta & Piasta & 35 \\
Słoneczny Stok & Osiedle Młodych & Słoneczny Stok & Osiedle Młodych & 31 \\
Dziesięciny & Centrum Wschód & Centrum Zachód & Sady Antoniukowskie & 30 \\
Leśna Dolina & Bażantarnia & Wiejska_Kawaleryjska & Bażantarnia & 30 \\
TBS & Wysoki Stoczek & Wysoki Stoczek & Wysoki Stoczek & 30 \\
Wiejska_Kawaleryjska & Piaski & Wiejska_Kawaleryjska & Piaski & 30 \\
Nowe Miasto & Piaski & Wiejska_Kawaleryjska & Nowe Miasto & 29 \\
Wiejska_Kawaleryjska & Kawaleryjska_Kleosin & Wiejska_Kawaleryjska & Piaski & 29 \\
Sienkiewicza_Wasilkowska & Centrum Wschód & Sienkiewicza_Wasilkowska & Sienkiewicza_Wasilkowska & 28 \\
Wysoki Stoczek & Centrum Wschód & Wysoki Stoczek & Wysoki Stoczek & 28 \\
Centrum Wschód & Centrum Wschód & Mickiewicza_urzędy & Centrum Zachód & 27 \\
\hline
\end{tabular}

An example of the use of sequence analysis for determining flows of passengers traveling from a specific location, in this case this is the Bacieczki Region.

Table 8

Example distribution of directions of movement of passengers

\begin{tabular}{|c|c|c|c|c|}
\hline Region 1 & Region 2 & Region 3 & Region 4 & $\begin{array}{r}\text { Number of } \\
\text { passengers }\end{array}$ \\
\hline Bacieczki & & & & 788 \\
Bacieczki & Pietrasze & & & 12 \\
Bacieczki & Pietrasze & Centrum Wschód & & 5 \\
Bacieczki & Pietrasze & Centrum Wschód & Skorupy_Przemysłowe & 2 \\
Bacieczki & Pietrasze & Centrum Zachód & & 5 \\
Bacieczki & Pietrasze & Centrum Zachód & Centrum Wschód & 2 \\
Bacieczki & Pietrasze & Centrum Zachód & Skorupy_Przemysłowe & 2 \\
Bacieczki & PKP_PKS & & & 34 \\
Bacieczki & PKP_PKS & Branickiego_Warszawska & & 2 \\
Bacieczki & PKP_PKS & Centrum Wschód & & 8 \\
Bacieczki & PKP_PKS & Centrum Wschód & Centrum Zachód & 2 \\
Bacieczki & PKP_PKS & Centrum Zachód & & 2 \\
Bacieczki & PKP_PKS & Osiedle Młodych & & 3 \\
Bacieczki & PKP_PKS & Sady Antoniukowskie & & 7 \\
Bacieczki & PKP_PKS & Wysoki Stoczek & & 4 \\
\hline
\end{tabular}




\section{Dorota Sokołowska}

An analysis of the data from the table above (which is a fragment of a complete compilation consisting of over 46,000 records) allows to make an observation concerning passenger traffic. The above example describes a fragment of the flow of passengers traveling from the Bacieczki Region in the direction of Pietrasze, the train station and the bus station. Out of the 788 passengers logging-in in Bacieczki, 12 went in the direction of Pietrasze, out of whom 5 went to Centrum Wschód (out of whom 2 persons went to Skorupy Przemysłowe), another 5 to Centrum Zachód (out of whom 2 persons to Centrum Wschód and 2 to Skorupy Przemysłowe); 34 passengers went from Bacieczki in the direction of the stations, out of whom 2 persons went further in the direction of Branickiego_Warszawska, 8 persons went in the direction of Centrum Wschód (out of whom 2 then went to Centrum Zachód), 2 persons went directly to Centrum Zachód, 3 persons went to Osiedle Młodych, etc.).

\section{Conclusions}

The organization and management of transport in municipal agglomerations is a huge challenge for the city officials and nowadays it requires knowledge gained by means of modern technologies and innovative uses of methods from various branches of science - statistical knowledge being the key area. Research in the field of public transport management is conducted all over the world and published in thousands of publications.

Despite the fact that the analysis was limited to passengers with electronic tickets (they could be called BKM's regular clients), the size of the database allows to determine the directions of movement of Białystok citizens with a high probability.

The city's public transport is arranged radially with a single transfer center, so it is possible to trace new bus routes in such a way that they would bypass the city center, which would allow to avoid traffic concentration in the center of the city and would certainly reduce the duration of a direct journey between selected Regions.

Knowing also the numbers of passengers and the main directions of flows of citizen movement, a possible construction of new roads, or a renovation of old ones, can be planned in order to improve the movement of BKM's fleet.

By selecting the most popular pairs of bus stops and thus the highest number of persons traveling between specific bus stops, new lines could be opened, or express buses could be arranged on the existing lines. 
The conducted analysis may serve as a support tool for the management of a public transport network, which, in addition to the aforementioned conclusions, would yield benefits in the form of an improvement of the comfort of traveling, or a reduction of the costs of management and energy consumption. This would also have a positive effect on environment protection and increase the competitiveness of bus transport over private car transport.

\section{R E F E R E N C E S}

Area and Population in the Territorial Profile in 2013. Statistical Information and Elaborations (2013), Warszawa: Central Statistical Office. Publication available on CD-ROM and at website - www.stat.gov.pl

Dytkowski, G., Gamrot, W., Tomanek, R. (2009). Wykorzystanie metod statystycznych w badaniu popytu na usługi transportu miejskiego. Prace Naukowe Akademii Ekonomicznej im. Karola Adamieckiego. Katowice: Wydawnictwo Akademii Ekonomicznej w Katowicach.

Gangrade, S., Pendyala, R. M., McCullough, R. G. (2002). A Nested Logit Model of Commuters' Activity Schedules, Journal of Transportation and Statistics, No 2/3. Bureau of Transportation Statistics Research and Innovative Technology Administration.

Harańczyk, G. (2010). Zastosowanie technik Data Mining w badaniach naukowych. Kraków: StatSoft Polska, www.statsoft.pl/czytelnia.html

Lerman, S. R. (1979). The use of Disaggregate Choice Models in Semi-Markov Process Models of Trip Chaining Behavior. Transportation Science, No 13. Massachusetts: Massachusetts Institute of Technology.

Linoff, G., Berry, M. (2011), Data Mining Techniques: For Marketing, Sales, and Customer Relationship Management. Indiana: Wiley Publishing, Inc., Indianapolis.

Łapczyński, M. (2009). Analiza koszykowa i analiza sekwencji - wielki brat czuwa Kraków: StatSoft Polska, www.statsoft.pl/czytelnia.html.

Migut, G. (2009). Czy stosowanie metod Data Mining może przynieść korzyści w badaniach naukowych? Kraków: StatSoft Polska, www.statsoft.pl/czytelnia.html.

Navick, D. S., Furth, P. G (2002). Estimating passengers miles, origin - destination patterns, and loads with location - stamped farebox data. Transportation Research Record. No 1799.

Zagóżdżon, B. (2003). Komunikacja miejska jako element sektora publicznego, $\mathrm{w}$ : Liberalizacja transportu $w$ warunkach transformacji gospodarczej, praca zbiorowa pod red. G. Dydkowskiego i R. Tomanka, Prace Naukowe Akademii Ekonomicznej im. Karola Adamieckiego, Katowice: Wydawn. Akad. Ekonomicznej im. Karola Adamieckiego w Katowicach.

http://www.stat.gov.pl/cps/rde/xbcr/gus/l_powierzchnia__ludnosc_przekroj_ terytorialny_2013.pdf. 